\title{
Specifika a komparace př́pravy vrcholových cyklistů s tělesným postižením
}

\section{Specifics of preparation and comparison of top cyclists with disabilities}

\author{
Marek Zaoral, Lucie Rybová, Ondřej Ješina \\ Fakulta tělesné kultury, Univerzita Palackého v Olomouci, \\ Česká republika
}

\section{Abstrakt:}

Silniční cyklistika je celosvětově rozšiřreným sportem. Tréninková př́prava je podstatnou složkou celého systému uplatnitelného ve vrcholné cyklistice. Ve výzkumném šetreni zjištujeme, jaké jsou rozdíly v tréninkové př́pravě silniční vrcholné cyklistiky osob s tělesným postižením a bez tělesného postižení. Výzkumného šetření se zúčastnilo celkem 6 respondentů, z toho 3 cyklisti s různým typem tělesného postižení (TP) a 3 cyklisti bez postižení s mezinárodními zkušenostmi. Výběr respondentů byl záměrný. $Z$ výsledků jsou patrné rozdily v tréninkové prípravě obou sledovaných skupin. Nejmarkantněji se rozdily projevily v celkové podpoře (finanční, materiální i týmové), absence průběžného zátěžového testování u skupin s TP, ve skladbě předsezónni připravy a využivání variabilní forem organizace př́pravy. Bylo rovněž zjištěno, že vybraní sportovci s TP maji vyšši počet tréninkových jednotek při zachování stejného objemu v týdenním tréninkovém režimu.

\section{Abstract:}

Road cycling is a widespread sport. Training preparation is an essential component of the system applicable in the peak of cycling. Our research is focused on the training differences of top road cyclists with 
disabilities and without disability. There were total 6 respondents in this research, 3 cyclists with different types of disability and 3 cyclists without disabilities with international experiences. The selection of respondents was intentional. The results are noticeable differences in the preparation of training both groups. Most obvious differences are reflected in the overall support (financial, material and team support), absence of stress testing in the groups of cyclists with disability and also in the composition of pre-season training and in the use of flexible forms of organization during training. It was also found that selected athletes with disability have a higher number of training sessions with the same volume at weekly training mode.

Klíčová slova: cyklistika, př́prava, tréninková jednotka, výživa, regenerace.

Key words: cycling, preparation, training unit, nutrition and regeneration.

\section{ÚVOD}

Počátky cyklistiky osob tělesně postižených dále jen (osoby TP) v České republice se datují od 80. let. Její kořeny vychází z rekreační cyklistiky, zakladatelem je František Dvouletý. Postupem času se vytvořily dvě základny, z toho jedna v Orlických horách, která byla zaměřena především na turistiku. Druhá základna vznikla v Praze a její zaměření se postupem času soustředilo na vrcholové závodní pojetí tělesně postižených cyklistů. Mezi hlavní představitele uvádíme Václava Svobodu a Josefa Lachmana. Druhý jmenovaný se zasloužil o to, že je cyklistika tělesně postižených jedním z nejúspěšnějších sportů osob s tělesným postižením. Josef Lachman se jako první zúčastnil Paralympijských her v Soulu v roce 1988, kde se mu podařilo získat stř́brnou medaili. Jeho sbírka cenných kovů se i nadále rozšiřovala, a to znamenalo i zvýšený zájem a rostoucí popularitu cyklistiky mezi tělesně postiženými Pá- 
nek, J. (2007). Od 80. let se pravidelně koná mistrovství České republiky a naši reprezentanti vyjíždějí na jejich první starty do zahraničí. Lze říci, že se od této doby začalo kolo využívat i jako výborný tréninkový prostředek pro ostatní sporty. Díky rostoucí popularitě se logicky začala objevovat i další jména, jako je Lubomír Šimovec, Jiří Ježek nebo Michal Stark, kteří navázali na skvělé úspěchy Josefa Lachmana. Cyklisté se zdravotním postižením dále jen (ZP) v České republice jsou od roku 2006 soustředěni pod hlavičku IPC (Mezinárodní paralympijský výbor) a od roku 2006 jsou na základě usnesení UCI (Mezinárodní cyklistická unie) součástí Českého svazu cyklistiky Černý, J. (2006).

\section{CÍL PRÁCE}

Šetření bylo realizováno $\mathrm{v}$ rámci závěrečné bakalářské práce, jejímž cílem bylo popsat specifika při sportovní prrípravě cyklistů s různým typem postižení a cyklistů bez zdravotního postižení. Prvním dílčím cílem je popis vybraných faktorů působících na individuální přípravu silničních vrcholových cyklistů. Druhým dílčím cílem práce je komparace sportovní prŕípravy u cyklistů s tělesným postižením a cyklistů bez postižení. Záměrem teoretické části práce je stručný popis historie a struktury organizací zaštit'ující cyklistiku ve světě i v České republice. Vývoj vrcholové cyklistiky v České republice s návazností na postavení vrcholové cyklistiky mezi ostatními sporty. Hlavním tématem je popis tréninku vrcholových cyklistů související s výživou a regenerací.

Dílčím cílem práce je pak analýza dostupné literatury, zpracování prrípadových studií u vybraných respondentů, provedení komparace v tréninkovém procesu, analýza získaných dat formou kazuistik a na základě získaných výsledků vyvození patřičných závěrů.

\section{VÝZKUMNÝ SOUBOR}

Cílovou skupinou výzkumu jsou vrcholoví silniční cyklisté, kteří jsou v reprezentaci ČR. Výzkumného šetření se účastnilo celkem 6 respondentů. První cílovou skupinu tvoří vrcholoví cyklisté z kategorie U23 bez zdravotního postižení ve věku 18-23 let. Druhou skupinou jsou 
cyklisté s tělesným postižením, z toho jeden sportovec s jednostrannou nadkolenní amputací dolní končetiny, sportovec s triplegickou formou dětské mozkové obrny, sportovec s poruchou hybnosti dolních končetin - diparetická forma po poranění páteře.

Respondenti byli vybráni záměrně na základě kriteria - reprezentant České republiky. Bylo vybráno a osloveno celkem 9 respondenti̊, $\mathrm{z}$ toho pouze 6 respondentů souhlasilo se zapojením do výzkumu. Ostatní 3 respondenti neprojevili zájem pro spolupráci.

\section{METODIKA}

Hlavní metodou použitou pro dosažení cílů této práce byla metoda dotazování, konkrétně pak strukturovaný rozhovor. Rozhovor byl aplikován prostřednictvím elektronického dotazování realizovaným mezi autorem práce a respondenty použitím emailu. Pro upřesnění některých informací byli respondenti dotazováni osobním kontaktováním. Sběr dat trval od 20. listopadu 2012 do 15. dubna 2013. Získaná data byla zpracována do podoby kazuistiky, která tedy byla další použitou strategií výzkumu. Kazuistika byla zpracována na základě norem uvedených ve skriptech od Hajdova (2012).

\section{VÝSLEDKY}

Vrcholová silniční cyklistka je velmi rozsáhlým sportem po celém světě. $Z$ důvodu velké rozšířenosti tohoto sportu nacházíme nové disciplíny a stále zlepšující se výsledky sportovců. Silniční cyklistku díky novodobým technologiím můžou využívat i osoby s tělesným postižením.

Ze získaných informací je patrné, že předsezonní prrípravy dvou srovnaných skupin se od sebe liší. Prvním faktem je rozdíl v místech konání předsezonní př́pravy v zimním a jarním období. Zatímco vrcholoví cyklisté bez tělesného postižení se pravidelně připravují na jihu Evropy - tedy v teplém kraji, tak vrcholový cyklisté s tělesným postižením se ve všech př́padech připravují na sezónu v tuzemsku. Tento fakt má velký vliv na kvalitu celé předsezonní př́ipravy, proto už v této fázi mohou vznikat výkonnostní rozdíly. Zcela překvapivým výsledkem je, že žádný 
z oslovených cyklistů s tělesným postižením neabsolvuje zátěžové testy před nebo během závodní sezóny. Všichni respondenti bez tělesného postižení pak absolvují zátěžové testy před závodní sezónou ale i v jejím průběhu. Tato okolnost je jednou z prvních zásad pro vytváření kvalitní přípravy každého vrcholového sportovce.

Rozdíly se objevují rovněž v tréninkových mikrocyklech, a to především v počtu tréninkových a regeneračních dní v jednom týdnu. Cyklisté s tělesným postižením mají mikrocyklus o jeden den delší než cyklisté bez tělesného postižení. To může vést k častější fázi přetrénovanosti, což může ovlivnit kvalitu fyzického výkonu a zejména pak celkové psychické pohody. Z výsledku je rovněž patrné, že vrcholový cyklisté s tělesným postižením nemají dostatek kvalifikovaných a plně kompetentních trenérů. Právě výběr trenérů může mít za následek mnohdy se objevující neprofesionální až amatérskou př́ípravu vrcholových sportovců $\mathrm{s}$ tělesným postižením. Proto velká část vrcholových cyklistů s tělesným postižením nemá zpracované tréninkové plány pro kvalitní předsezonní přípravu. Příčin nedostatku kvalifikovaných trenérů muže být celá řada, $\mathrm{z}$ nichž nejpodstatnější jsou především ekonomické důvody, či absence klubů pro výchovu talentovaných vrcholových cyklistu s tělesným postižením a rovněž potřebné literatury z této oblasti.

\section{ZÁV̌̌R}

Období přípravy cyklistů na nadcházející sezónu je důležité k získání základní výkonnosti a zajištění jejího růstu. Základní princip spočívá ve zvyšování trénovanosti. Podcenění přípravné části má za následek stagnaci výkonnosti v průběhu závodního období. Pro cyklisty je přípravné období charakterizováno najížděním kilometrů neboli objemové tréninky, k získávání aerobní vytrvalosti. Jarní přípravu lze tedy považovat za nejpodstatnější období celého roku.

Práce se zabývá porovnáním předsezonní př́pravy vrcholových cyklistů bez tělesného postižení a osob s tělesným postižením. Ze získaných výsledků je patrné, že nejvíce zásadním faktorem ovlivňujícím celkovou prrípravu a následně výsledky cyklistů s postižením je jejich 
týmová ekonomická situace. Komplexní příprava vrcholových cyklistů s tělesným postižením na nadcházející sezónu je pak srovnatelná jako př́íprava amatérských cyklistů bez tělesného postižení.

\section{LITERATURA}

Černý, J.(2006). Onás-historie Českého vazu cyklistiky. Retrieved 24. 10. 2012 from the World Wide Web: http://www.ceskysvazcyklistiky.cz/ clanek/73_o_nas.

Pánek, J. (2007). Cyklistika osob s amputací dolní končetiny a její specifika. Diplomová práce.

\section{KONTAKT:}

Marek Zaoral, Marek.Zaoral@seznam.cz 